\title{
Platelet Count and Platelet Indices in Pregnant Saudi Women with Gestational Diabetes Mellitus
}

\author{
Osama M Alshehri* \\ Department of Clinical Laboratory, Najran University, Saudi Araba
}

Submission: April 14, 2021; Published: April 23, 2021

*Corresponding author: Osama M Alshehri, Department of Clinical Laboratory, Applied Medical Sciences College, Najran University, Najran, Saudi Araba

Keywords:

Aim: To evaluate the differences in platelet count and platelet indices in the second trimester of pregnancy between pregnant women with gestational diabetes mellitus (GDM) and apparently healthy pregnant women.

Methods: A cross-sectional study was performed with 60 pregnant women with GDM (cases) and 60 apparently healthy pregnant women (controls). The study groups were matched in terms of baseline characteristics; complete blood counts were done to determine platelet counts and platelet indices.

Results: The mean total platelet count, MPV, PDW and P-LCR were significantly increased in pregnant women with GDM compared to the apparent healthy pregnant women (P value $=0.00$ ). MPV was well correlated with PDW and P-LCR, and PDW was directly correlated with P-LCR.

Conclusion: The high platelet count and the significant changes in platelet indices on CBC testing in the second trimester of pregnancy were most probably due to the presence GDM.

Keywords: Gestational diabetes mellitus; Complete blood counts; Platelet indices

Abbreviations: MPV: Mean Platelet Volume; PDW: Platelet Distribution Width; P- LCR: Platelet Large Cell Ratio; GDM: Gestational Diabetes Mellitus; PLR: Platelet Count to Lymphocyte Ratio; NLR: Neutrophil to Lymphocyte Ratio; EDTA: Ethylene Diamine Tetra Acetic Acid

\section{Introduction}

Gestational diabetes mellitus (GDM) is one of the most common chronic diseases associated with pregnancy among women. In the literature, it is the most common medical problem during pregnancy, and it is observed mostly in old and obese pregnant women with strong family histories of diabetes mellitus [1,2]. GDM is diagnosed when there is an increase in the blood sugar level that occurs for the first time in pregnant women without any history of diabetes mellitus. The disease usually occurs between the $24^{\text {th }}$ and $28^{\text {th }}$ week of pregnancy and may appear shortly before or after $[3,4]$. The hormones secreted during pregnancy antagonize the action of insulin, and so in pregnant women, there is an increase in demand for insulin production from the pancreas to overcome the insulin resistance. Pregnant women who are obese and old as well as those who have a family history of diabetes, are unable to produce enough insulin, and this leads to the development of gestational diabetes $[4,5]$. This disease results in high rates of prenatal and maternal mortality as well as long- term complications for the mother and child. Therefore, the early detection and treatment of the disease is important in reducing these risks [6].

In spite of extensive research spanning several decades, there is no consensus on a method for screening for GDM [1]. The most used method for diagnosing gestational diabetes was proposed by the International Diabetes Federation. In this method, pregnant women at 24-28 weeks of gestation are screened using fasting blood sugar one and two hours after the intake of $75 \mathrm{~g}$ of glucose. GDM is diagnosed if FBS is $92-125 \mathrm{mg} / \mathrm{dl}$ or if a patient has a one-hour blood sugar of $180 \mathrm{mg} / \mathrm{dL}$ or more or a two-hour blood sugar of $153 \mathrm{mg} / \mathrm{dL}$ or more [4].

The global estimated prevalence of GDM is $13.2 \%$ [7]. According to national studies, the prevalence of gestational diabetes among Saudi women is high compared to the global prevalence $15 \%-39.4 \%$ [8-10]. This is a result of the advanced age 


\section{Current Research in Diabetes \& Obesity Journal}

and prevalence of obesity in pregnant Saudi women at conception [8]. Early changes in blood cell components in pregnant women with gestational diabetes resulting from chronic and mild inflammation are due to the pathogenesis of insulin resistance [1]. White blood cells and platelets play an important role in reducing inflammation as their numbers increase in acute and chronic inflammation [11].

Inflammatory parameters, such as platelet count to lymphocyte ratio (PLR) and neutrophil to lymphocyte ratio (NLR) can be calculated using complete blood count (CBC) test results [12]. The platelet count and indices, including mean platelet volume (MPV), platelet distribution width (PDW) and platelet large cell ratio (P-LCR) from the $\mathrm{CBC}$ test provide important information on the occurrence of gestational diabetes [13-15]. A group of international studies have suggested a change in platelet indices in pregnant women with GDM. A study done in China found MPV values to be higher in pregnant women with GDM compared to their healthy counterparts [16]. Other studies revealed an increase in platelet count in women with GDM compared to women without the disease [17].

However, a study in China reported insignificant differences in platelet parameters between diabetic and non- diabetic pregnant women [18]. Although there has been a lot of research on the relationship between platelet indices and GDM, the conflicting research results engender debate and controversy. Hence, this study aimed to evaluate the differences in platelet count and platelet indices in the second trimester of pregnancy between pregnant women with GDM and apparently healthy pregnant women.

\section{Materials and Methods}

A cross-sectional, case-control study was conducted in Najran University Hospital, Najran, Saudi Arabia between June 2020 and March 2021. Sixty pregnant women between 24-32 weeks of pregnancy and between 25-39 years, who were diagnosed with GDM according to the International Diabetes Federation criteria [4], formed the test group, and sixty healthy pregnant women matched for age, comprised the control group. Non-pregnant Saudi women and those with known hematological disorders were excluded from this study.

data between case and control groups.
An interview with a questionnaire was conducted to determine the baseline characteristics and clinical information of all pregnant women in this study. The clinical examination was carried out by physicians working at Najran University Hospital. Weight and height were measured to obtain BMI using the weight (kg) per height $\left(\mathrm{m}^{2}\right)$ formula. A 2-ml sample of venous blood was collected from each participant into tubes containing ethylene diamine tetra acetic acid (EDTA). The samples were analyzed immediately to avoid changes in platelet size. The Sysmex XN-350 blood counter (Sysmex, Japan) was used to measure total platelet count, MPV, PDW and P-LCR.

\section{Ethical considerations}

The Ethics and Research Committee of Najran University approved the protocol of this study. The objectives of this study were discussed with the participants. Informed consent was obtained from all participants before sample collection.

\section{Statistical analysis}

The data from this study was statistically analyzed using SPSS version 21. Independent samples t-test and one- way ANOVA were performed to determine the differences between the test and control groups. Correlation was done and $\mathrm{r}$ values were obtained. $P$ values $<0.05$ were considered significant.

\section{Results}

The current study enrolled 120 subjects who were selected according to inclusion criteria and allocated to two groups. Sixty pregnant women with GDM were selected as cases and 60 apparently healthy pregnant women, as controls. The study groups were matched in terms of baseline characteristics, and no significant differences regarding these characteristics were noted (Table 1). The mean values of total platelet count, MPV, PDW and P-LCR were significantly higher in the GDM group compared to the control group (P value $=0.00$ ) (Table 2). In the GDM group, MPV was directly correlated with PDW and P-LCR, and PDW was directly correlated with P- LCR. On the other hand, a significant negative correlation between platelet count and PDW and P-LCR and an insignificant negative correlation between platelet count and MPV were found (Table 3).

Table 1: Statistics and mean differences of demographic and medical

\begin{tabular}{|c|c|c|c|}
\hline Variables & Cases $(\mathbf{n}=\mathbf{6 0})$ & Controls (n = 60) & P value \\
\hline Age (years) & $29.4 \pm 6.9$ & $27.8 \pm 6.3$ & 0.78 \\
\hline Gestational age (weeks) & $25.80 \pm 0.99$ & $25.70 \pm 0.81$ & 0.43 \\
\hline Weight $(\mathrm{kg})$ & $66.0 \pm 8.7$ & $68.1 \pm 9.1$ & 0.32 \\
\hline Height $(\mathrm{cm})$ & $160.2 \pm 6.0$ & $161.7 \pm 5.7$ & 0.13 \\
\hline BMI $(\mathrm{kg} / \mathrm{m} 2)$ & $25.4 \pm 2.8$ & $25.6 \pm 2.7$ & 0.28 \\
\hline
\end{tabular}

$P$ values $<0.05$ considered significant. 


\section{Current Research in Diabetes \& Obesity Journal}

Table 2: Statistics and mean differences of total platelet count, MPV, PDW and P-LCR between case and control groups.

\begin{tabular}{|c|c|c|c|}
\hline Variables & Cases $(\mathbf{n}=\mathbf{6 0})$ & Controls $(\mathbf{n}=\mathbf{6 0})$ & P value \\
\hline Platelet count $\left(\times 10^{3} / \mu \mathrm{m}\right)$ & $228.65 \pm 78.3$ & $192.07 \pm 55.7$ & 0 \\
\hline MPV (fl) & $10.11 \pm 1.9$ & $8.61 \pm 1.5$ & 0 \\
\hline PDW (\%) & $13.5 \pm 1.7$ & $11.6 \pm 0.9$ & 0 \\
\hline P-LCR (\%) & $24.96 \pm 8.7$ & $16.60 \pm 3.7$ & 0 \\
\hline
\end{tabular}

$P$ values $<0.05$ considered significant.

Table 3: Correlations between platelet count and indices in the GDM group.

\begin{tabular}{|c|c|c|c|c|c|}
\hline \multicolumn{2}{|c|}{ GDM } & \multirow[t]{2}{*}{ Platelet count $\left(\times 10^{3} / \mu \mathrm{m}\right.$} & \multirow{2}{*}{$\begin{array}{c}\text { MPV (fl) } \\
-0.218 \\
\end{array}$} & \multirow{2}{*}{$\begin{array}{c}\text { PDW (\%) } \\
-0.39 \\
\end{array}$} & \multirow{2}{*}{$\begin{array}{c}\text { P-LCR (\%) } \\
-0.3 \\
\end{array}$} \\
\hline & $\mathrm{r}$ value & & & & \\
\hline Fideretcount $(x 10 / \mu \operatorname{lin})$ & $\mathrm{p}$ value & & 0.094 & 0.002 & 0.02 \\
\hline \multirow{2}{*}{ MPV (fl) } & $\mathrm{r}$ value & -0.218 & & 0.35 & 0.564 \\
\hline & $\mathrm{p}$ value & 0.094 & & 0.006 & 0 \\
\hline \multirow{2}{*}{ PDW (\%) } & $\mathrm{r}$ value & -0.39 & 0.35 & & 0.772 \\
\hline & $\mathrm{p}$ value & 0.002 & 0.006 & & 0 \\
\hline \multirow{2}{*}{ P-LCR (\%) } & $\mathrm{r}$ value & -0.3 & 0.564 & 0.772 & \\
\hline & $\mathrm{p}$ value & 0.02 & 0 & 0 & \\
\hline
\end{tabular}

$P$ values $<0.05$ considered significant.

\section{Discussion}

GDM is a significant but frequently overlooked risk factor for a mother's future health. About $15-18 \%$ of women with histories of GDM will suffer from type 2DM within the first five years after pregnancy $[19,20]$. Although this risk for type 2 diabetes mellitus is well established for women with GDM, there have been previous studies on this issue in women with GDM [20,21]. Our study results suggest that platelet count and indices in the second trimester were highly correlated with the occurrence of GDM.

We found that the platelet count, MPV, PDW and P-LCR values for the GDM group were higher than those for the healthy control group. Our results agreed with those of Fashami \& Elnour, et al. [13] and Hope et al. [22], showing that in the second trimester of pregnancy, women with GDM had significantly elevated platelet counts, MPV, PDW and P-LCR compared to healthy pregnant women. Platelets are known to play an important and essential role in homeostasis and thrombosis, and many studies have indicated that platelets may also be critically involved in intercellular communication, inflammatory activity, and immunization [11]. In addition, chronic and mild inflammation are key elements in the pathogenesis of insulin resistance in type 2 diabetes. Among the immune elements, platelets are critical in regulating inflammation as high platelet counts are observed in chronic and acute inflammation [23].

GDM is a systemic disease that affects both the mother and fetus [1]. These patients have an increased risk of developing type 2 diabetes and must therefore be closely monitored. Increased MPV and PDW may reflect increased platelet activation, and thus, additional research on platelet parameters and functions may assist in reducing the mortality and morbidity associated with GDM. Contrary to our finding, Erdoğan et al. [24] found that there were no significant variations in the mean values of platelet count and MPV between healthy pregnant women and those with GDM. The reason for this result was the low number of participants enrolled in the study. We found that MPV was correlated with PDW and P-LCR, and PDW was directly correlated with P-LCR. This is consistent with the finding of Sak et al. [25] that average MPV values were significantly increased in patients with gestational diabetes, and the MPV was positively correlated with PDW and platelet count.

\section{Conclusion}

This study confirmed that there is a correlation between platelet indices in pregnant women in the second trimester with gestational diabetes. Women with GDM had higher platelet counts, MPV, PDW and P-LCR compared to healthy pregnant women. MPV and PDW had the strongest association of all indices with the occurrence of GDM in the second semester, and this had significant clinical implications. Given the critical nature of early diagnosis of GDM, additional research in the early stages of pregnancy is necessary to determine whether early intervention can improve pregnancy outcomes.

\section{Acknowledgment}

The author appreciates the collaboration of all pregnant women who participated in this study. 


\section{Current Research in Diabetes \& Obesity Journal}

\section{References}

1. Cunningham FG (2018) William's obstetrics. In: F Gary Cunningham, Kenneth J Leveno, Steven L Bloom, et al. (Eds.), Spong McGraw-Hill Education, New York, USA.

2. Fashami MA, Hajian S, Afrakhteh M, Khoob MK (2020) Is there an association between platelet and blood inflammatory indices and the risk of gestational diabetes mellitus? Obstet Gynecol Sci 63(2): 133140

3. Garrison A (2015) Screening, diagnosis, and management of gestational diabetes mellitus. Am Fam Physician 91(7): 460-467.

4. International Diabetes Federation (2011) Management of gestational diabetes in the community: training manual for community helath workers. Int Diabetes Fed [Internet] 1-20.

5. John P Bantle, Judith Wylie Rosett, Ann L Albright, Caroline M Apovian, et al. (2008) Nutrition recommendations and interventions for diabetes: a position statement of the American Diabetes Association. Diabetes Care 31(Suppl 1): S61-S78.

6. Lindsay RS (2009) Gestational diabetes: causes and consequences. Br Diabetes Vasc Dis 9(1): 27-31.

7. Melchior H, Kurch Bek D, Mund M (2017) The prevalence of gestational diabetes: a population-based analysis of a nationwide screening program. Dtsch Arztebl Int 114(24): 412-418.

8. Alsaedi SA, Altalhi AA, Nabrawi MF, Aldainy AA, Wali RM (2020) Prevalence and risk factors of gestational diabetes mellitus among pregnant patients visiting National Guard primary health care centers in Saudi Arabia. Saudi Med J 41(2): 144-150.

9. Wahabi H, Fayed A, Esmaeil S, Mamdouh H, Kotb R (2017) Prevalence and Complications of Pregestational and Gestational Diabetes in Saudi Women: Analysis from Riyadh Mother and Baby Cohort Study (RAHMA). Biomed Res Int 1-9.

10. Alfadhli EM, Osman EN, Basri TH, Mansuri NS, Youssef MH, et al. (2015) Gestational diabetes among Saudi women: prevalence, risk factors and pregnancy outcomes. Ann Saudi Med 35(3): 222-230.

11. Choi JL, Li S, Han JY (2014) Platelet function tests: a review of progresses in clinical application. Biomed Res Int 2014: 45656.

12. Cha HH, Kim JM, Kim HM, Kim MJ, Chong GO, et al. (2021) Association between gestational age at delivery and lymphocyte-monocyte ratio in the routine second trimester complete blood cell count. Yeungnam Univ J Med 38(1): 34-38.

13. Elnour S, Rahim A, Muddathir M (2013) Assessment of mean platelet volume and platelets histogram among Sudanese pregnant women with gestational diabetes mellitus. Am J Res Commun 1(12): 445-450.

14. Vernekar PV, Ananda Vaidya K (2013) Comparison of mean platelet volume in type 2 diabetics on insulin therapy and on oral hypoglycaemic agents. J Clin Diagnostic Res 7(12): 2839-2840.

15. Raza SA, Hassan M, Badar F, Rasheed F, Meerza F, et al. (2019) Cardiovascular disease risk factors in Pakistani population with newly diagnosed type 2 diabetes mellitus: a cross-sectional study of selected family practitioner clinics in four provinces of Pakistan (CardiP Study). J Pak Med Assoc 69(3): 306-612.

16. Zhou Z, Chen H, Sun M, Ju H (2018) Mean platelet volume and gestational diabetes mellitus: a systematic review and meta-analysis. J Diabetes Res 1985026.

17. Hongling Y, Chunyan Z, Qinling M, Yan ZC (2015) Variations of blood cells in prediction of gestational diabetes mellitus. J Perinat Med 43: 89-93.

18. Chen X, Fang L, Lin H, Shen P, Zhang T, et al. (2017) The relationship between type 2 diabetes and platelet indicators. Iran J Public Health 46(9): 1211-1116.

19. Webb J (2013) Diagnosis and treatment of gestational diabetes. Nurse Prescr 11(1): 14-20.

20. Golden SH, Bennett WL, Baptist Roberts K, Wilson LM, Barone B, et al. (2009) Antepartum glucose tolerance test results as predictors of type 2 diabetes mellitus in women with a history of gestational diabetes mellitus: A systematic review. Gend Med 6: 109-122.

21. Åberg AEB, Jönsson EK, Eskilsson I, Landin Olsson M, Frid AH (2002) Predictive factors of developing diabetes mellitus in women with gestational diabetes. Acta Obstet Gynecol Scand 81(1): 11-16.

22. Hope O, Ifeanyi OE, N AQB (2019) Investigation of some haematologica parameters in pregnant women with gestational diabetes at Federal Medical Center, Owerri , Imo State , Nigeria. Ann Clin Lab Res 7(2:305): $1-6$.

23. Mertoglu C, Gunay M (2017) Neutrophil-lymphocyte ratio and plateletlymphocyte ratio as useful predictive markers of prediabetes and diabetes mellitus. Diabetes Metab Syndr Clin Res Rev 11: S127-131.

24. Erdoğan S, Özdemir Ö, Doğan HO, Sezer S, Atalay CR, et al. (2014) Liver enzymes, mean platelet volume, and red cell distribution width in gestational diabetes. Turkish J Med Sci 44(1): 121-125.

25. Sak ME, Soydinç HE, Özler A, Evsen MS, Turgut A, et al. (2012) Gestasyonel diabetik hastalarda trombosit profili: Retrospektif değerlendirme. J Turkish Ger Gynecol Assoc 13(4): 223-226.



Your next submission with Juniper Publishers
will reach you the below assets
- Quality Editorial service
- Swift Peer Review
- Reprints availability
- E-prints Service
- Manuscript Podcast for convenient understanding
- Global attainment for your research
- Manuscript accessibility in different formats
( Pdf, E-pub, Full Text, Audio)
- Unceasing customer service
Track the below URL for one-step submission
https://juniperpublishers.com/online-submission.php

